\title{
Naturally Occurring Autoantibodies against $\beta$-Amyloid: Investigating Their Role in Transgenic Animal and In Vitro Models of Alzheimer's Disease
}

\author{
Richard Dodel, ${ }^{1}$ Karthikeyan Balakrishnan, ${ }^{1}$ Kathy Keyvani, ${ }^{2}$ Oliver Deuster, ${ }^{1}$ Frauke Neff, ${ }^{1}$ \\ Luminita-Cornelia Andrei-Selmer, ${ }^{1}$ Stephan Röskam, ${ }^{1}$ Carsten Stüer,${ }^{3}$ Yousef Al-Abed ${ }^{4}$ Carmen Noelker, ${ }^{1}$ \\ Monika Balzer-Geldsetzer, ${ }^{1}$ Wolfgang Oertel, ${ }^{1}$ Yansheng Du, ${ }^{5}$ and Michael Bacher ${ }^{1}$ \\ ${ }^{1}$ Department of Neurology, Philipps University Marburg, D-35043 Marburg, Germany, ${ }^{2}$ Institute of Pathology and Neuropathology, University of Essen, \\ D-45147 Essen, Germany, ${ }^{3}$ Department of Neurosurgery, Technische Universität München, D-81675 Munich, Germany, ${ }^{4}$ Laboratory of Medicinal \\ Chemistry, The Feinstein Institute for Medical Research, Manhasset, New York 11030, and 5 Department of Neurology, Indiana University Medical School, \\ Indianapolis, Indiana 46202
}

\begin{abstract}
Alzheimer's disease $(\mathrm{AD})$ is a neurodegenerative disorder primarily affecting regions of the brain responsible for higher cognitive functions. Immunization against $\beta$-amyloid $(\mathrm{A} \beta)$ in animal models of $\mathrm{AD}$ has been shown to be effective on the molecular level but also on the behavioral level. Recently, we reported naturally occurring autoantibodies against A $\beta$ (NAbs-A $\beta$ ) being reduced in Alzheimer's disease patients. Here, we further investigated their physiological role: in epitope mapping studies, NAbs-A $\beta$ recognized the mid-/Cterminal end of $\mathrm{A} \beta$ and preferentially bound to oligomers but failed to bind to monomers/fibrils. NAbs-A $\beta$ were able to interfere with $\mathrm{A} \beta$ peptide toxicity, but NAbs-A $\beta$ did not readily clear senile plaques although early fleecy-like plaques were reduced. Administration of NAbs-A $\beta$ in transgenic mice improved the object location memory significantly, almost reaching performance levels of wild-type control mice. These findings suggest a novel physiological mechanism involving NAbs-A $\beta$ to dispose of proteins or peptides that are prone to forming toxic aggregates.
\end{abstract}

\section{Introduction}

Alzheimer's disease $(\mathrm{AD})$ is a neurodegenerative disorder primarily affecting regions of the brain responsible for higher cognitive functions, such as learning and memory. Plaque deposition and neurofibrillary tangles are the histopathological hallmarks of $\mathrm{AD}$. $\beta$-Amyloid $(\mathrm{A} \beta$ ) peptides become deposited in those plaques, and hence their clearance has been discussed as a major therapeutic goal.

Emerging experimental evidence detected the early acidic endosomes as the principal generation site for $\mathrm{A} \beta$ peptides (Kaether et al., 2006; Rajendran et al., 2006), and dimers, trimers, and multimeric aggregates have been shown recently in vitro and in transgenic ( $\mathrm{Tg}$ ) mice models to be crucial toxic species (Cleary et al., 2005; Klyubin et al., 2005; Lesné et al., 2006; Townsend et al., 2006; Glabe, 2008; Shankar et al., 2008; Tomic et al., 2009). It was further suggested that small A $\beta$ oligomers may form intracellularly before being released into the extracellular medium, in which they

\footnotetext{
Received Aug. 21, 2010; revised Nov. 16, 2010; accepted Dec. 12, 2010.

This study was supported by an unrestricted research grant of the University Medical Center Giessen and Marburg (UKGM) (PN: 155/06-07MR) and in part by an unrestricted grant of the Deutsche Forschungsgemeinschaft Grant D0784/2-1. We also received an unrestricted grant from Prof. Dr. Reinfried Pohl, Marburg, Germany. We thank Caroline Gäckler for the excellent technical assistance and Tanja Rausch for the histopathological work.

R.D. and M.B. hold patents on immunization with autoantibodies in neurodegenerative disorders.

Correspondence should be addressed to Dr. Richard Dodel, Department of Neurology, Philipps University Marburg, Baldingerstrasse, 35043 Marburg, Germany. E-mail: dodel@med.uni-marburg.de.

DOI:10.1523/JNEUROSCI.4401-10.2011

Copyright $\odot 2011$ the authors $\quad 0270-6474 / 11 / 315847-08 \$ 15.00 / 0$
}

may interfere with synaptic activity or act as seeds to accelerate fibril formation (Selkoe, 2004; Khandogin and Brooks, 2007). Thus, preventing or reversing the formation of aggregated amyloid would appear to be a promising strategy for AD treatment.

Several therapeutic approaches are currently under consideration, including active/passive immunization against $A \beta$ as pioneered by Schenk et al. (1999). In transgenic amyloid precursor protein (APP)-expressing mice, immunization against $\mathrm{A} \beta$ peptides has been shown to be effective on both molecular and behavioral levels. Active immunization in transgenic mice reduced fibril formation, promoted clearance of $\mathrm{A} \beta$ plaques, and also interfered with tau phosphorylation (Schenk et al., 1999; Morgan et al., 2000). Moreover, passive immunization was also effective with antibodies that recognized the N-terminal and the mid-terminal domains of $A \beta$ peptides (DeMattos et al., 2001). Based on these data, several clinical trials have been started (Mangialasche et al., 2010). In patients treated with antibodies directed against the $\mathrm{N}$ terminus of $\mathrm{A} \beta$, a considerable decrease in plaque load has been reported, but clearance of already formed plaques might not be sufficient to improve cognitive function in $\mathrm{AD}$ patients (Holmes et al., 2008).

Recently, we and others identified naturally occurring autoantibodies against $\mathrm{A} \beta$ (NAbs- $\mathrm{A} \beta$ ) being reduced in patients with AD (Du et al., 2001; Weksler et al., 2002). Naturally occurring autoantibodies make up to two-thirds of the human antibody pool and are known to have many functions; however, the underlying mechanisms are far from being completely understood (Shoenfeld et al., 2007). NAbs-A $\beta$ have been characterized in 
different experimental settings to inhibit the propensity of $A \beta$ to fibrillize, thereby blocking its toxicity and to affect the clearance of A $\beta$ (Dodel et al., 2004; Taguchi et al., 2008; Bacher et al., 2009; Relkin et al., 2009). However, how NAbs-A $\beta$ interact with $A \beta$ and promote their clearance remains to be elucidated. Here, we show for the first time that NAbs-A $\beta$ interfered with, and preferentially bound to early oligomerization products of $\mathrm{A} \beta$ peptide. Moreover, in a mouse model of $A D$, plaque formation was reduced after passive immunization with NAbs-A $\beta$ and the subsequent clearance of $A \beta$ led to a rapid improvement of mice behavior.

Based on the concept of NAbs-A $\beta$, commercially available human Ig preparations (IVIg) have been used in small pilot trials for the treatment of patients with AD (Dodel et al., 2010), which showed promising effects on cognition, thus leading to a phase III trial in the United States (Relkin et al., 2009).

\section{Materials and Methods}

Isolation of $N A b s-A \beta$. We used purified human intravenous IgG (Octagam $5 \%$ ) for the isolation of NAbs-A $\beta$, which was kindly provided by Octapharma AG. Octagam 5\% liquid is a solvent/detergent-treated, sterile preparation of highly purified IgG derived from large pools of human plasma (10,000-20,000 of donations). The product is prepared by using cold Cohn-Oncley ethanol fractionation process, followed by ultrafiltration and chromatography and contains $\sim 50 \mathrm{mg}$ of protein per milliliter (5\%). Ninety-six percent of protein represents human normal IgG (IgA $<0.2 \mathrm{mg}$; IgM $<0.1 \mathrm{mg}$ ). It contains no more than $3 \%$ aggregates and fragments, respectively, and no more than $90 \%$ monomers and dimers with an Fc portion maintained intact. IgG subclasses are fully represented (IgG 1, 65\%; IgG 2, 30\%; IgG 3, 3\%; IgG 4, 2\%). For the following isolation steps, this preparation was mixed with an equal volume of PBS and loaded directly onto an affinity column.

Because the $A \beta_{1-40}$ sequence contains internal lysine residues that might lead to side reactions in immobilization procedures using amino groups, a specific affinity column was prepared using a cysteine residue attached to the $\mathrm{A} \beta \mathrm{N}$ terminus to ensure homogeneous orientation of peptide molecules on the column support by immobilization through cysteinyl-S-thioether linkage. The azlactone-activated support contains an iodoacetyl group (Ultralink; Perbio) at the end of a hexadecyl-spacer group, which reacts with the cysteinyl-sulfhydryl group to yield a stable thioether linkage to reduce steric hindrance and provide maximum binding capacity of the antibodies. For covalent attachment of the Cys$\mathrm{A} \beta_{1-40}, 3.7 \mathrm{mg}$ of peptide was dissolved in $50 \mathrm{~mm}$ Tris and $5 \mathrm{~mm}$ EDTA-Na coupling buffer, $\mathrm{pH} 8.5$, to a final concentration of $0.37 \mathrm{mg} /$ $\mathrm{ml}$. The solution was added to $1 \mathrm{ml}$ of drained Ultralink-Iodoacetyl gel, and the coupling reaction was performed for $1 \mathrm{~h}$ at room temperature under gentle mixing, followed by $30 \mathrm{~min}$ reaction time without mixing. An aliquot of $0.5 \mathrm{ml}$ of the $\mathrm{Cys}-\mathrm{A} \beta_{1-40}$ coupled support was packed into a column ( $2.5 \mathrm{ml}$; MoBiTec) allowing the solution to drain. The column was washed with $3 \mathrm{ml}$ of coupling buffer, and nonspecific binding sites on the gel were blocked two times for $45 \mathrm{~min}$ with $1 \mathrm{ml}$ of $50 \mathrm{~mm}$ L-cysteine$\mathrm{HCl}$ in coupling buffer. Subsequently, the column was washed with $5 \mathrm{ml}$ of $1 \mathrm{M} \mathrm{NaCl}, 5 \mathrm{ml}$ of $0.1 \mathrm{M} \mathrm{Na}$-phosphate, and $0.15 \mathrm{M} \mathrm{NaCl}, \mathrm{pH} 7.2$, and stored at $4^{\circ} \mathrm{C}$. The gel support $(0.5 \mathrm{ml})$ was transferred into a $15 \mathrm{ml}$ Falcon vial using $5 \mathrm{ml}$ of PBS and mixed with $5 \mathrm{ml}$ of IVIg. After gentle shaking overnight at $4^{\circ} \mathrm{C}$, this suspension was transferred to the column using the effluent to completely rinse the matrix back into the column. The column was washed eight times with $10 \mathrm{ml}$ of PBS, followed by two wash cycles with $10 \mathrm{ml}$ of ultrapure water.

The bound antibodies were eluted from the column with $10 \times 0.5 \mathrm{ml}$ of $0.1 \mathrm{~m}$ glycine buffer, $\mathrm{pH} 2.8$. Each fraction was collected in a microreaction tube containing $35 \mu \mathrm{l}$ of $1 \mathrm{~m}$ Tris- $\mathrm{HCl}, \mathrm{pH}$ 9. The flow-through (FT) of this isolation procedure, which contains IgG depleted of NAbs$\mathrm{A} \beta$, was also collected and was used as a control in the respective experimental settings.

To maintain the integrity of the antibodies, a neutral $\mathrm{pH}$ was adjusted immediately after elution by adding the appropriate amount of Tris-HCI

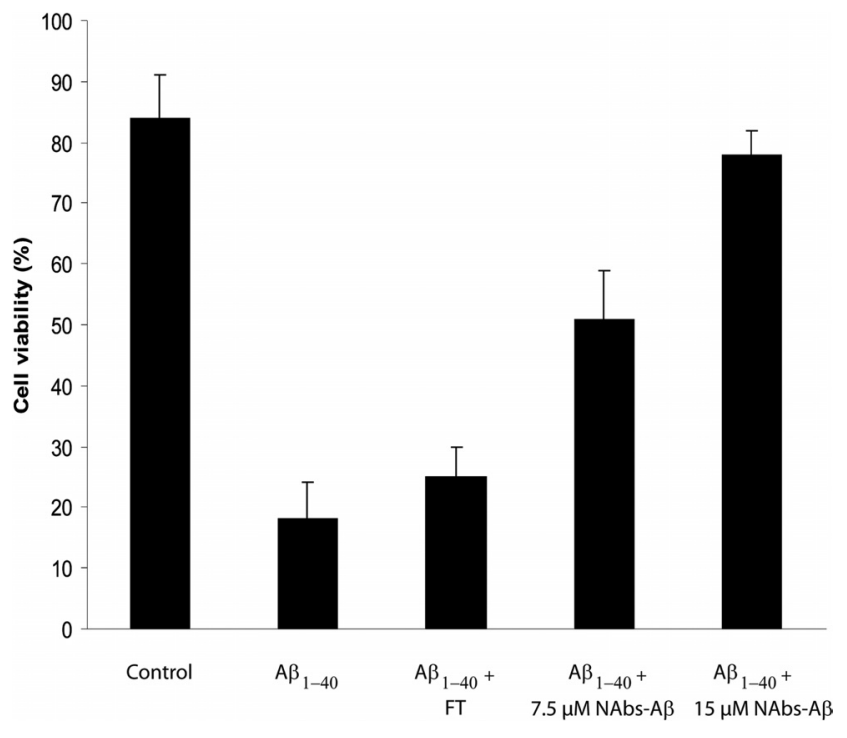

Figure 1. NAbs-A $\beta$ were able to block the neurotoxic effect of oligomeric $A \beta_{1-40}$ in neuroblastoma SH-SY5Y cells. SH-SY5Y cells (30,000 cells per well) were incubated alone or in the presence of oligomerized $A \beta_{1-40}$ (prepared as described in Material and Methods). The viability of the cells was determined by the MTT assay. There was a concentration-dependent inhibition of $A \beta$-induced cell death in the presence of NAbs-A $\beta$. At a concentration of $15 \mu \mathrm{m} N A b s-A \beta$, an almost complete inhibition of $A \beta$-induced cell death was observed. Using the FT in a concentration up to $15 \mu \mathrm{m}$ did not block $A \beta$-induced cytotoxicity. Values are expressed as percentage of control cultures for each experiment, and the data represent the mean \pm SE of triplicate determinations from a representative experiment repeated at least three times with similar results.

or glycine buffer. To regenerate the column for additional use, the column was washed once with $10 \mathrm{ml}$ of $10 \mathrm{~mm} \mathrm{Na-phosphate} \mathrm{buffer,} \mathrm{pH} 6.8$, followed by two wash cycles with $10 \mathrm{ml}$ of PBS containing $1 \mathrm{M} \mathrm{NaCl}$ and finally two wash cycles with $10 \mathrm{ml}$ of PBS.

Antibody concentrations in the elution fractions were determined by the Micro BCA Protein Assay kit method (Pierce; Perbio). The stock solution of $2 \mathrm{mg} / \mathrm{ml}$ bovine albumin supplied within the Micro BCATM kit was used to prepare fresh standard dilutions within the range 40-0.5 $\mu \mathrm{g} / \mathrm{ml}$. The antibodies were eluted between fractions 1 and 6 , with the highest concentrations in fractions 1 and 3 . For quantification of each set of 10 elutions, fresh albumin standard dilutions were prepared. Results were read at $562 \mathrm{~nm}$ with an ELISA reader.

Cell culture and toxicity assay. SH-SY5Y human neuroblastoma cells were grown in RPMI 1640 medium supplemented with 10\% FCS, $10 \mathrm{~mm}$ HEPES, $4 \mathrm{~mm}$ glutamine, penicillin $(200 \mathrm{U} / \mathrm{ml})$, and streptomycin $(200$ $\mu \mathrm{g} / \mathrm{ml})$ at $37^{\circ} \mathrm{C}$ in a $5 \% \mathrm{CO}_{2}$ atmosphere. Cells were plated and kept overnight at a density of 30,000 cells per well in a 96-well microtiter plate. After removal of medium, cells were washed with PBS, and toxic A $\beta$ oligomers ( $2 \mu \mathrm{M}$ final concentration) (Kayed et al., 2003) were added in $100 \mu \mathrm{l}$ of fresh medium with either 7.5 or $15 \mu \mathrm{M}$ NAbs-A $\beta$ or without NAbs-A $\beta$. Each data point was determined in hexaplicate. MTT toxicity assay with SH-SY5Y cells was performed according to the protocol of the manufacturer.

Preparation of $A \beta$. The lyophilized synthetic $\mathrm{A} \beta_{1-40}$ (PSL GmbH) was resuspended in $100 \% 1,1,1,3,3,3$ hexafluoro-2-propanol (HFIP) at 1 $\mathrm{mg} / \mathrm{ml}$ and incubated for $1 \mathrm{~h}$ at room temperature. After evaporation of HFIP, the peptide was resuspended according to the species of interest. For preparation of the monomer, the synthetic $\mathrm{A} \beta_{1-40}$ peptide was suspended in ultrapure or double-distilled water at $1 \mathrm{mg} / \mathrm{ml}$ just before the experiment. $\mathrm{A} \beta$ dimers were prepared using $\mathrm{A} \beta_{1-40}$ peptide with $\mathrm{N}$-terminal cysteine $\left(\mathrm{Cys}-\mathrm{A} \beta_{1-40}\right)$ in $1 \times \mathrm{PBS}$ at $1 \mathrm{mg} / \mathrm{ml}$ concentration and centrifuged for $30 \mathrm{~min}$ at $12,000 \mathrm{rpm}$. The protein content of the supernatant was quantified using Nanodrop and sonicated for $15 \mathrm{~min}$ at $65^{\circ} \mathrm{C}$. The dimer was generated by incubation at $37^{\circ} \mathrm{C}$ for $3 \mathrm{~h}$ with shaking $(900 \mathrm{rpm})$. The trimer was generated by a double mutation of $\mathrm{A} \beta_{1-40}$ peptide and resuspended in sodium carbonate buffer $(1 \mathrm{mg} / \mathrm{ml}), \mathrm{pH} 9.6$, 
A

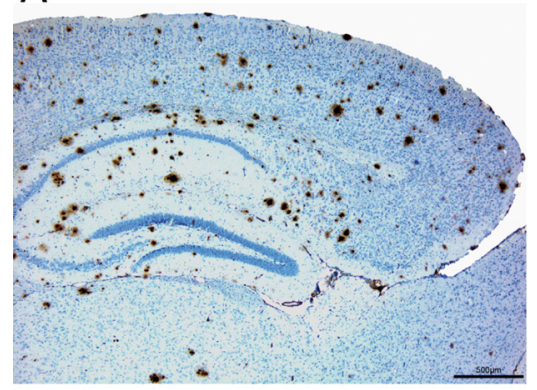

E

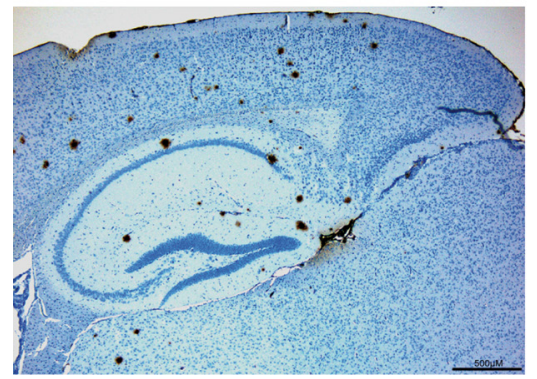

B

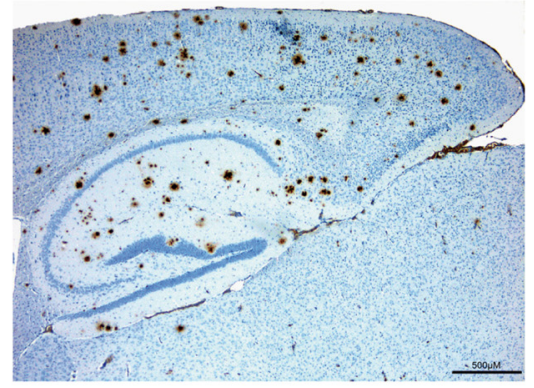

F

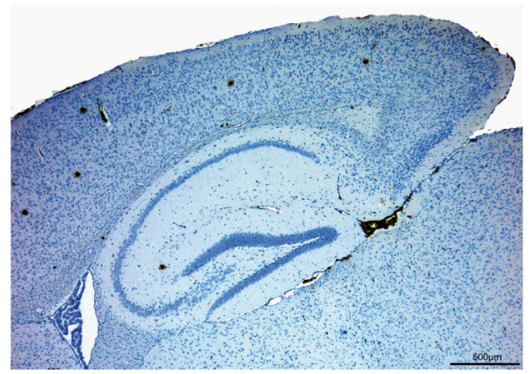

C

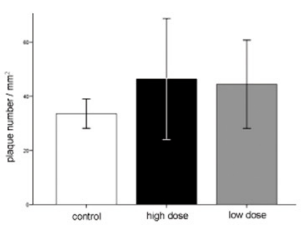

G
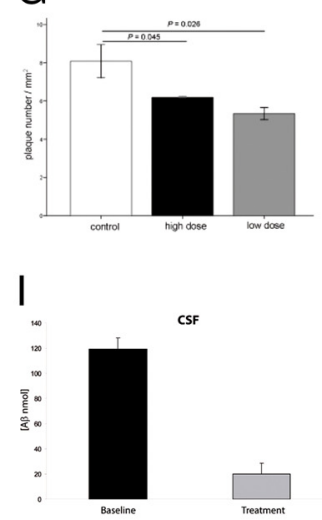

D

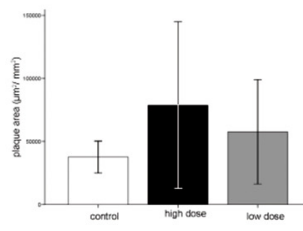

$\mathrm{H}$
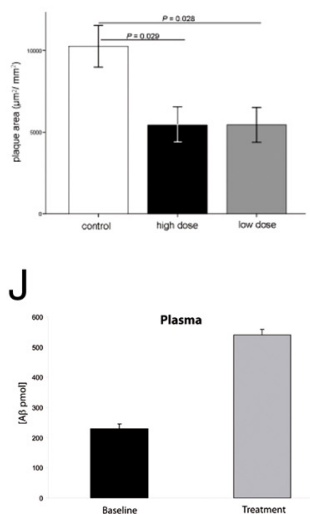

Figure 2. Effect of NAbs-A $\beta$ on plaque deposition and plaque load in transgenic APP TgCRND8 mice. $\boldsymbol{A}-\boldsymbol{D}$, Effect of NAbs-A $\beta$ on plaque number ( $(\boldsymbol{C})$ and plaque area (D) in old (age, 13 months) transgenic APP TgCRND8 mice. Transgenic mice were injected intraperitoneally once a week for the duration of 4 weeks with either FT after NAbs-A $\beta$ purification as control (control, $200 \mu \mathrm{g} ; A ; n=$ 10) or with a low $(80 \mu \mathrm{g} ; \boldsymbol{C}, \boldsymbol{D} ; n=7)$ and high $(200 \mu \mathrm{g} ; \boldsymbol{B}-\boldsymbol{D} ; n=8)$ dose of NAbs-A $\beta$, respectively. $\boldsymbol{E}-\boldsymbol{H}$, Effect of NAbs-A $\beta$ on plaque number $(\boldsymbol{G})$ and plaque area $(\boldsymbol{H})$ in young transgenic mice (age, 4 months). Transgenic mice were injected intraperitoneally once a week for the duration of 4 weeks with either FT (flow-through depleted of NAbs-A $\beta ; 200 \mu g ;$ control; $E ; n=7$ ) or a low ( 80 $\mu \mathrm{g} ; \boldsymbol{G}, \boldsymbol{H} ; n=7)$ and high (200 $\mu \mathrm{g} ; \boldsymbol{F}-\boldsymbol{H} ; \boldsymbol{n}=8$ ) dose of NAbs-A $\boldsymbol{\beta}$, respectively. In old TgCRND8 mice, NAbs-A $\beta$ did not affect the plaque load when compared with vehicle (FHT)-treated animals $(\boldsymbol{B}-\boldsymbol{D})$, whereas in young mice plaque number and plaque area was significantly suppressed after 4 weeks of treatment $(\boldsymbol{F}-\boldsymbol{H})$. The plaque density was significantly reduced after 4 weeks of both high (by 24\%) and low (by 34\%) dose treatment with NAbs-A $\beta$ ( $p=0.045$ and 0.026 , respectively; the difference between the low and the high dose in the respective figures was not significant). Furthermore, a reduction of plaque area by $47 \%$ was detected after high $(p=0.029)$ and low $(p=0.028)$ dose applications of NAbs-A $\beta(\boldsymbol{H})$. Animals were killed $5 \mathrm{~d}$ after the last injection. Sagittal sections from FT- and NAbs-A $\beta$-treated young and old mice were stained for $A \beta$ using anti-human $A \beta$ monoclonal antibody $6 F / 3 D$. The average number $(\boldsymbol{C}, \boldsymbol{G})$ and area $(\boldsymbol{D}, \boldsymbol{H})$ of $A \beta$ immunoreactive deposits were quantified semiautomatically in the cortex and hippocampus (12 sections per brain were analyzed). Results were analyzed using a two-tailed Student's $t$ test. Error bars represent the SD. $I, J$, Concentration of A $\beta$ in CSF and plasma of APP transgenic mice after treatment with NAbs-A $\beta$. The concentration of A $\beta$ in $(S F(I)$ and plasma $(J)$ was determined after the last treatment with NAbs-A $\beta$. There was an increase of the $A \beta$ concentration in the plasma and a decrease of the $A \beta$ concentration in CSF.

after the HFIP treatment, which instantly formed the SDS-stable trimer. Low-binding minicentrifuge tubes were used (Eppendorf) throughout the experiments.

Characterization of $A \beta$ epitopes recognized by $N A b s-A \beta$. Ninety-sixwell plates were coated with $\mathrm{A} \beta_{1-40}$ and other peptides as outlined in the respective figure [ $5 \mu \mathrm{g} / \mathrm{ml}$; freshly resuspended in coating buffer $(1.7 \mathrm{mM}$ $\mathrm{NaH}_{2} \mathrm{PO}_{4}, 98 \mathrm{~mm} \mathrm{Na}_{2} \mathrm{HPO}_{4}, \mathrm{pH} 7.4$, and $0.05 \%$ sodium azide)], and incubated at $37^{\circ} \mathrm{C}$ for $2 \mathrm{~h}$. The plates were then incubated with blocking buffer (Pierce) at $37^{\circ} \mathrm{C}$ for $2 \mathrm{~h}$.

HRP-labeled heavy and light chain-specific goat anti-human antibodies were used as detection antibodies at 1:3000 dilution and incubated for $1 \mathrm{~h}$ at $37^{\circ} \mathrm{C}$ (Calbiochem). The reaction with a chromogenic substrate, $3,3^{\prime}, 5,5^{\prime}$-tetramethylbenzidine (Calbiochem), was terminated with $2 \mathrm{~N}$ $\mathrm{H}_{2} \mathrm{SO}_{4}$, and plates were read at $450 \mathrm{~nm}$ using a plate reader (Thermo Fisher Scientific).

Size exclusion chromatography. A Superdex 75 10/30 HR column attached to an AKTA FPLC system (GE Healthcare) was used for all experiments and calibrated using unbranched dextran standards of the following molecular masses: 123,$600 ; 66,700 ; 43,800 ; 21,400 ; 9890$; and $4440 \mathrm{Da}$ (Pharmacosmos). $\beta$-Amyloid $(1 \mathrm{mg} / \mathrm{ml})$ was injected onto the Superdex 75 column and eluted with $50 \mathrm{~mm}$ ammonium acetate, $\mathrm{pH} 8.5$, at a flow rate of $1 \mathrm{ml} / \mathrm{min}$. One milliliter fractions were lyophilized, resuspended in $2 \times$ SDS-tricine sample buffer $(20 \mu \mathrm{l})$, boiled for $10 \mathrm{~min}$, and then subjected to electrophoresis on $10-20 \%$ tricine gels. Proteins were transferred onto $0.2 \mu \mathrm{m}$ nitrocellulose membranes and used for Western blotting.

Surface plasmon resonance experiments. Immobilization of antibodies and antibody/ $\mathrm{A} \beta$ interaction analyses were performed on a Biacore 2000 optical biosensor system. Each antibody was immobilized via amino coupling (Biacore) up to 8500-10,000 response units on CM5 sensor chips
(Biacore). Then, $60 \mu \mathrm{l}$ of analyte (A $\beta$ oligomers) was injected on sensor chips surfaces at a flow rate of $15 \mu \mathrm{l} / \mathrm{min}$ and in various concentrations $(0.1-100 \mu \mathrm{g} / \mathrm{ml})$. PBS and a carbonate-bicarbonate buffer were used as running buffers as specified. $\mathrm{A} \beta$ samples were kept at $4^{\circ} \mathrm{C}$ before each injection over the sensor chip at $25^{\circ} \mathrm{C}$. Surface plasmon resonance (SPR) chip regeneration was performed using $6.25-50 \mathrm{~mm} \mathrm{NaOH}$. Binding analysis was performed using BIA evaluation 3.2RC1 software (Biacore).

Animals and drug treatment. We investigated female CRND8 transgenic mice carrying a double-mutated form of the human amyloid precursor protein 695 (APP695; the Swedish and Indiana mutations) under the control of the Syrian hamster prion promoter, on a hybrid C57BL/ 6- $\mathrm{C} 3 \mathrm{H} / \mathrm{HeJ}$ background (courtesy of D. Westaway, University of Toronto, Toronto, Canada) (Chishti et al., 2001). Compared with other murine models of $\mathrm{AD}$ (Röskam et al., 2010), TgCRND8 mice exhibit A $\beta$ plaques at a very young age (at $\sim 3$ months), accompanied by cognitive deficits (Lovasic et al., 2005; Bacher et al., 2008). At 3 months ("young"; $n=15$ ) or 12 months ("old"; $n=15$ ) of age, mice were injected intraperitoneally once a week for the duration of 4 weeks with either a low ( 80 $\mu \mathrm{g})$ or high $(200 \mu \mathrm{g})$ dose of NAbs-A $\beta$ or with $200 \mu \mathrm{M}$ FT $(n=5)$. In all experiments, the column FT was used as negative control (see above). In addition, female APP23 transgenic mice, which express the human APP751 isoform with the Swedish double mutation (K670N-M671L) under control of a murine Thy1.2 expression cassette (courtesy of Dr. Matthias Staufenbiel, Novartis Institutes for Biomedical Research, Basel, Switzerland) were used. The animals were hemizygous or littermate controls and had been backcrossed with C57BL/6J mice for at least eight generations (Sturchler-Pierrat et al., 1997). Mice were housed in groups of three to four animals in standard cages $(37 \mathrm{~cm}$ length $\times 21 \mathrm{~cm}$ width $\times$ $15 \mathrm{~cm}$ height) together with wild-type littermates with food and water 
A

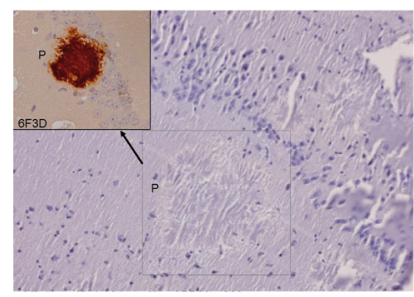

C

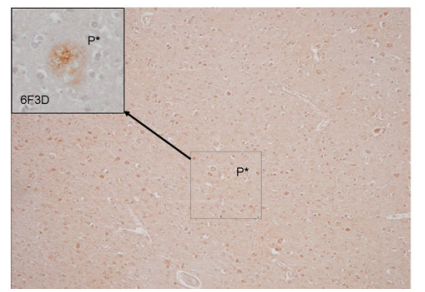

B

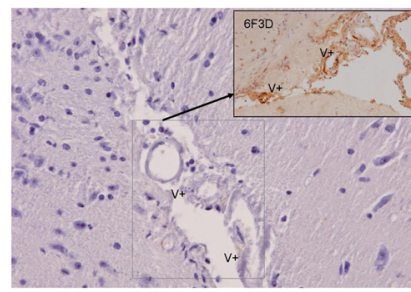

D

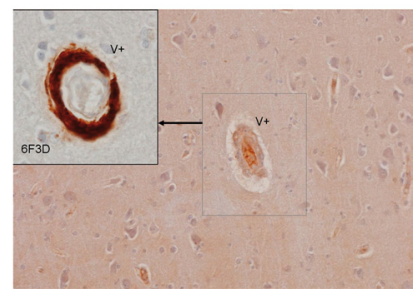

Figure 3. Immunohistochemistry to investigate the binding properties of the N-terminal monoclonal antibodies and NAbs-A $\beta$ to amyloid deposits in transgenic APP23 mice and in brain samples of $A D$ and human cerebral amyloid angiopathy. APP23 mice were used in this set of experiments because of their higher deposition of $A \beta$ in vasculature. Similar results were detected with respect to amyloid deposition in TgCRND8 mice. $A$, Immunostaining of a brain sample from an APP23 mouse with NAbs$A \beta$ : no specific staining of the plaque $(P)$ in the cortex is detectable. The inset represents the identical area with a positive staining using the $6 \mathrm{~F} / 3 \mathrm{D}$ monoclonal antibody. $\boldsymbol{B}$, Immunostaining of a brain sample from an APP23 mouse with NAbs-A $\beta$ : no specific staining of amyloid deposits in the vessel $(V+)$ is detectable (the inset represents the identical area with positive staining using the $6 \mathrm{~F} / 3 \mathrm{D}$ monoclonal antibody). $C$, Immunostaining of a brain sample from an AD patient with NAbs-A $\beta$ : no specific staining of a plaque $(P)$ is detectable. The inset represents the identical area with positive staining using the $6 \mathrm{~F} 3 \mathrm{D}$ monoclonal antibody. $\boldsymbol{D}$, Immunostaining of a brain sample from a cerebral amyloid angiopathy patient with NAbs-A $\beta$ : no specific staining of amyloid deposits in the small vessels $(\mathrm{V}+)$ is visible, but there are some unspecific chromogen reactions with the Nissl substance. The inset represents the identical area with positive staining using the $6 \mathrm{~F} 3 \mathrm{D}$ monoclonal antibody.

available ad libitum. All experimental procedures were in accordance with the guidelines of the local animal care commission.

Brain tissue preparation. Mice were decapitated $5 \mathrm{~d}$ after the last injection. Brains were removed, and one hemisphere was immediately snapfrozen in liquid nitrogen and kept at $-80^{\circ} \mathrm{C}$ until use. The other hemisphere was fixed in $4 \%$ buffered formaldehyde for $24 \mathrm{~h}$, followed by dehydration and paraffin embedding.

Immunohistochemistry. For $\mathrm{A} \beta$ staining, six pairs of $2 \mu \mathrm{m}$ sagittal brain sections of each transgenic animal were pretreated with formic acid and incubated in a TechMate instrument (Dako) with $6 \mathrm{~F} / 3 \mathrm{D}$ (anti-A $\beta$ monoclonal antibody directed against residues 8-17; 1:100; Dako). The second step used the Dako StreptABC complex horseradish peroxidaseconjugated anti-mouse/rabbit antibody kit, and staining was developed with 3,3-diaminobenzidine. Counterstaining was performed with hematoxylin. The pairs of sections (10 $\mu \mathrm{m}$ distances) were situated 100, 200, $300,400,500$, and $600 \mu \mathrm{m}$ laterally from the midsagittal fissure. All slides were stained in five consecutive procedures, ensuring that the brains of all three experimental groups were equally distributed.

Morphometry of the $A \beta$ plaques. To quantify the $\mathrm{A} \beta$ plaque burden, neocortices and hippocampi of all stained sections were digitized (Olympus BX50, ColorView II, charge-coupled device camera; Olympus) under constant light and filter settings. Color images were converted to grayscale by extracting blue to gray values to obtain the best contrast between positive immunoreactivity and the background. A constant threshold was chosen for all images to detect immunoreactive staining (analySIS 5; Soft Imaging System). The total number and size of plaques were determined. Absolute values of plaque burden were related to the investigated area.

Behavioral experiments. Fourteen- to 16-month-old Tg2576 mice expressing the Swedish mutation (K670N/M671L) of APP695 under the control of the hamster prion promoter, on a hybrid C57BL/6-SJL background (Hsiao et al., 1996), were intraperitoneally injected with either

$400 \mu \mathrm{g}$ of NAbs-A $\beta$ dissolved in $200 \mu \mathrm{l}$ of PBS $(n=21)$ or $200 \mu \mathrm{l}$ of PBS only $(n=20)$. An additional group of age-matched wild-type mice were treated with PBS $(n=20)$.

To investigate the treatment efficacy of NAbs $-\mathrm{A} \beta$ on spatial memory, we performed the object location test (Hale and Good, 2005). In brief, animals are introduced to two identical objects in an experimental apparatus and, after a delay, are exposed again to the same two objects, one of which has been displaced to a new location. Animals that remember the previous exposure spontaneously spend more time exploring the object in the new position. On the day of testing, mice were submitted to two 10 min trials with a $30 \mathrm{~min}$ intertrial delay. In trial 1 , mice were allowed to explore two similar objects located on one side of the cage for $10 \mathrm{~min}$. In trial 2, one of these objects was moved to a different location, and the mice were allowed to explore the object for another $10 \mathrm{~min}$. For analysis, a discrimination ratio (DR) (time spent on the object in the new location versus the total time spent exploring both objects in the test trial) was calculated for each mouse. Object location test was reflected by more time spent interacting with the object in the new location than with the object in the familiar position and a DR above 0.5. Analysis of DRs is less subject to the influence of individual variability in contact times with objects and provides a measure of the extent of the discrimination between the novel and sample objects.

Murine anti-human antibody response. To investigate the murine antihuman antibody (MAHA) response, we treated 10 wild-type mice (C57 $\mathrm{BL} / 6$ genetic background of TgCRND8 mice used in drug treatment experiments) with $200 \mu \mathrm{g}$ of NAbs-A $\beta$ once a week for a period of $28 \mathrm{~d}$ (Imboden et al., 2001). Blood was taken before and after the treatment and investigated by MAHA ELISA. Briefly, plates were coated overnight at $4^{\circ} \mathrm{C}$ with $5 \mu \mathrm{g} / \mathrm{ml}$ human $\operatorname{IgG} 1$, diluted in sodium bicarbonate buffer, $\mathrm{pH}$ 9.6. After washing four times with $1 \times$ PBS, $0.05 \%$ Tween 20 , pH 7.4, plates were blocked for $3 \mathrm{~h}$ with SuperBlock (Thermo Fisher Scientific). After washing four times with $1 \times$ PBS, $0.05 \%$ Tween 20 , pH 7.4, the serum samples were diluted 1:100 and added to the wells for overnight incubation at $4^{\circ} \mathrm{C}$. The wells were then washed four times with $1 \times \mathrm{PBS}$ and $0.05 \%$ Tween $20, \mathrm{pH} 7.4$, and then $0.1 \mu \mathrm{g} / \mathrm{ml} \mathrm{HRP-conjugated} \mathrm{goat}$ anti-mouse IgG was added and plates were incubated for $1 \mathrm{~h}$ at room temperature. Plates were then washed four times with $1 \times \mathrm{PBS}$ and $0.05 \%$ Tween 20, pH 7.4. A total of $100 \mu$ l of tetramethylbenzidine (Calbiochem) substrate was added to each well. The plates were incubated for 10 $\mathrm{min}$, and then the reaction was stopped by the addition of $25 \mu \mathrm{l} /$ well of $2 \mathrm{~N} \mathrm{H}_{2} \mathrm{SO}_{4}$. The plates were read at $450 \mathrm{~nm}$ with a $570 \mathrm{~nm}$ reference filter. The standard curve reagent used for this assay was obtained by performing these measurements on serial dilutions of mouse anti-human IgG1 (BD Biosciences Pharmingen) in concentrations between 1 and 1000 $\mathrm{ng} / \mathrm{ml}$ in twofold increments.

Statistical analysis. Data were analyzed using the Student's $t$ test or ANOVA as appropriate. All tests were applied (two tailed) using the software package SPSS (version 12.0.1). Differences were considered significant at $p<0.05$.

\section{Results}

To assess whether purified NAbs-A $\beta$ were protective against $A \beta$ induced cell death, we used $\mathrm{A} \beta$ preparations consisting of oligomerized products (Kayed et al., 2003). NAbs-A $\beta$ were able to block the toxic effects of $\mathrm{A} \beta$ oligomers in SH-SY5Y cells in a concentration-dependent manner (Fig. 1). Cell death was reduced by $>80 \%$ in the presence of NAbs $-\mathrm{A} \beta$. Ig preparations lacking NAbs-A $\beta$ (flow-through of IVIg after isolation of NAbs$\mathrm{A} \beta$ ) administered at concentrations up to $15 \mu \mathrm{M}$ were not able to block the cytotoxic effects in this assay (Fig. 1).

Therapeutic efficacy of immunization has been associated with the clearance of plaques in the brain of transgenic mice (Schenk et al., 1999). Therefore, we investigated the ability of NAbs-A $\beta$ to resolve plaque burden in APP TgCRND8 transgenic mice (Chishti et al., 2001). We examined the effect of a low (80 $\mu \mathrm{g})$ and high $(200 \mu \mathrm{g})$ dose of purified NAbs $-\mathrm{A} \beta$ on $\mathrm{A} \beta$ plaque deposition by immunohistochemical staining and image analysis 


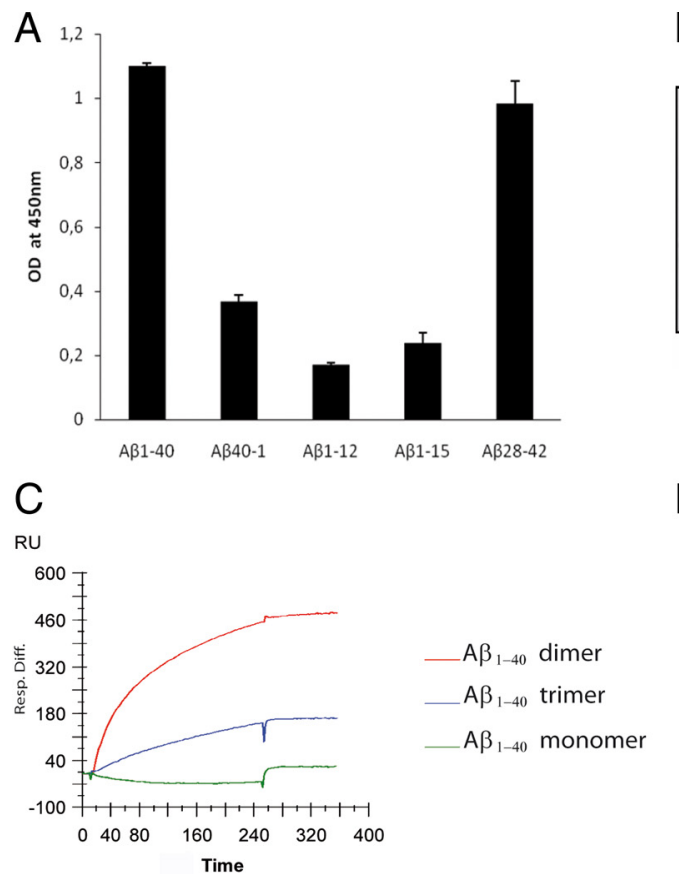

B

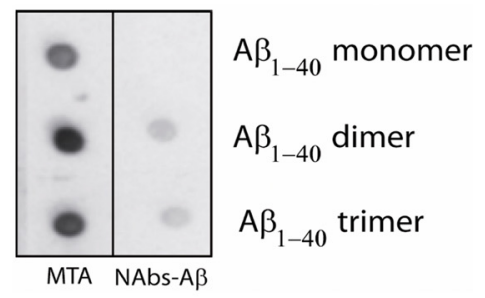

$\mathrm{D}$
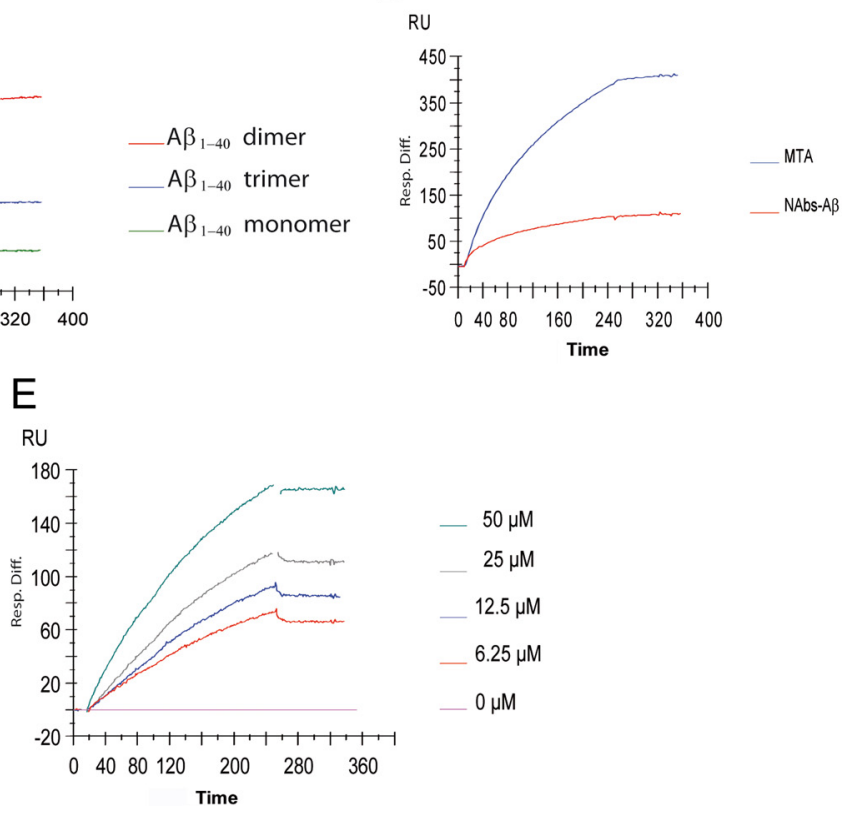

Figure 4. $\quad A$, Mapping of the $A \beta$ epitope recognized by NAbs-A $\beta$ using ELISA. Various peptides representing different parts of the $A \beta$ sequence were tested for the avidity of NAbs- $A \beta$ to bind in ELISA. The binding experiments showed an increased binding of the NAbs-A $\beta$ toward the $C$-terminal region. We identified sequence $A A 28-40(42)$ as the major binding site. N-terminal regions of the $A \beta$ peptide showed only low binding with the $A \beta$ reversed sequence $\left(A \beta_{40-1}\right)$. The following peptides (with and without exchanged amino acids) were also investigated: $A \beta_{1-40} ; A \beta_{1-42} ; A \beta_{1-12} ; A \beta_{1-15} ; A \beta_{10-28} ; A \beta_{20-38 ;} ; A \beta_{20-31} ; A \beta_{25-40} ;$

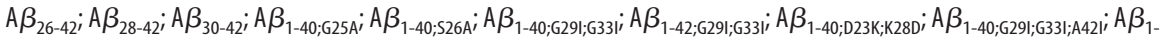

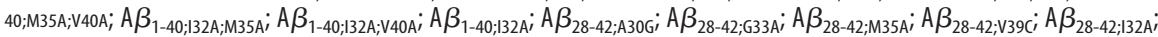
$A \beta_{28-42 ; 132 A ; M 35 A ; V 40 A} \cdot \boldsymbol{B}$, Dot blots of various peptide samples of SEC fractions of $A \beta$ were applied on nitrocellulose membrane $(0.25 \mu \mathrm{g} / 3 \mu \mathrm{l} \mathrm{spot})$. The mid-terminal antibody (MTA) directed against residues AA16-24 readily recognized monomeric and oligomeric forms of $A \beta$, whereas $N A b s-A \beta$ only interacted with dimeric and trimeric forms but not monomeric forms. $C-\boldsymbol{E}$, Immobilization and interaction analyses of monoclonal antibodies and $N A b s-A \beta$ to $A \beta_{1-40}$ and its different oligomeric forms were performed on a Biacore 2000 optical biosensor system. C, NAbs-A $\beta$ preferentially bound to dimers, and also to trimers, but not to the monomeric form of $A \beta$. D. The on-rate of the monoclonal antibody MTA to $A \beta$ was higher compared with the on-rate of $N A b s-A \beta$. $E$, There was a dose-dependent on-rate of the binding of NAbs-A $\beta$ to $A \beta_{1-40} .0 D, 0$ ptical density; $R U$, response units.

in young ( 4 months) and old (13 months) TgCRND8 mice. To avoid the MAHA response, treatment with the foreign antibody was limited to 4 weeks to prevent an adverse MAHA immune response in the animal model. To investigate the MAHA response, we injected 10 mice with $200 \mu$ g of NAbs-A $\beta$ once a week for $28 \mathrm{~d}$. As expected, all animals developed Ig against human IgG (baseline, $0.001 \mathrm{mg} / \mathrm{ml}$; at $28 \mathrm{~d}, 0.017 \mathrm{mg} / \mathrm{ml}$ ). However, the titers were low within the group of 10 animals, seven animals had a titer of $<0.01 \mathrm{mg} / \mathrm{ml}$, and only one animal $(0.06 \mathrm{mg} / \mathrm{ml})$ had a titer above $0.05 \mathrm{mg} / \mathrm{ml}$. None of the animals died or exhibited clinical or behavioral changes. None of the inspected organs showed changes as investigated by pathological and histopathological examinations.
The cerebral plaque load in senescent animals remained unaffected after 4 weeks of treatment with either low or high doses of NAbs-A $\beta$ when compared with age-matched sham-treated animals (Fig. $2 A-D)$. In contrast, both low- and high dose-treated young transgenic mice had a significant reduction of plaque number (high dose, by $24 \%, p=0.045$; low dose, by $34 \%, p=0.026$ ) and plaque area (high dose, by $47 \%, p=0.029$; low dose, by $47 \%, p=0.028$ ) (Fig. $2 E-H$ ). The differences between the high and the low doses in young animals were not significant.

A disturbance in the equilibrium of the central and the peripheral pool of $A \beta$ was assumed to take place after immunization against $\mathrm{A} \beta$; a phenomenon termed "peripheral sink hypothesis" (Dodart et al., 2002; Dodel et al., 2002). Because the NAbs-A $\beta$ had no plaque-dissolving benefit in the old animals, we further investigated their effect on the concentration of $\mathrm{A} \beta$ in CSF and plasma of immunized animals. We detected a significant reduction of CSF $A \beta$ in the animal group treated with NAbs-A $\beta$ (Fig. 2). In plasma, an increase of $A \beta$ was detectable, indicating an efflux of $A \beta$ from the central pool into the periphery (Fig. $2 J$ ). In contrast, CSF and plasma levels of $\mathrm{A} \beta$ did not change considerably when treated with FT for the same period.

Interestingly, NAbs- $\mathrm{A} \beta$ failed to detect plaques in brain samples of transgenic APP-expressing mice (Fig. $3 A, B$ ), AD patients (Fig. $3 C$ ), and patients with cerebral amyloid angiopathy (Fig. 3D). In contrast, antibodies such as 6F/3D detected plaques in both animal and human brain samples. Similar results were found when NAbs-A $\beta$ was used to detect $A \beta$ in the brain vasculature of patients with cerebral amyloid angiopathy (Fig. 3D).

Antibodies raised against the $\mathrm{A} \beta$ epitopes 4-10 have been reported to bind to plaques in the brains of transgenic animals (McLaurin et al., 2002). Therefore, we determined the linear sequences and the conformational epitopes that were recognized by NAbs-A $\beta$ using a large set of synthetic peptides derived from the $\mathrm{A} \beta$ sequence (Fig. $4 A$ ). The NAbs-A $\beta$ bound to the full-length $A \beta$ but not to the albumin control. The epitope region recognized by NAbs- $\mathrm{A} \beta$ encompassed the residues $28-40(42)$ of the $\mathrm{A} \beta$ sequence (Fig. $4 A$ ), whereas $\mathrm{N}$-terminal fragments were not recognized by NAbs-A $\beta$. The peptides with an altered amino acid as well as the scrambled peptide did not show a binding signal. The relevant amino acids within the epitope were confirmed by an alanine scan of the C-terminal region of $\mathrm{A} \beta$.

Using size exclusion chromatography to separate monomeric, dimeric, and trimeric forms of $A \beta$ as described previously (Walsh et al., 2005), we found that NAbs-A $\beta$ preferentially recognized dimers and trimers and, to a lesser extent, monomeric forms of 
$\mathrm{A} \beta$ (Fig. $4 B$ ). In contrast, a monoclonal antibody recognizing the mid-terminal part of the $A \beta$ sequence detected all three investigated $\mathrm{A} \beta$ oligomers. The affinity of NAbs $-\mathrm{A} \beta$ to the different $\mathrm{A} \beta$ assemblies using SPR are shown in Figure $4 C-E$.

Furthermore, in behavioral experiments in the Tg2576 transgenic mice, the object location memory improved significantly after the administration of NAbs-A $\beta$ and almost reached performance levels of wild-type control mice. Mice treated with PBS regularly performed at chance levels (discrimination ratio: $0.5=$ $50 \%$ ), whereas NAbs-A $\beta$-treated animals and age-matched wildtype mice performed above chance ( $p<0.001$, ANOVA) (Fig. 5).

\section{Discussion}

To the best of our knowledge, this is the first report to link naturally occurring autoantibodies to a physiological effect in the metabolism of peptides that are toxic to humans. We found that NAbs-A $\beta$ were readily detectable in healthy individuals, interacted with $A \beta$, and promoted its degradation. In epitope mapping, NAbs-A $\beta$ detected the mid-/C-terminal epitope of $\mathrm{A} \beta$, starting at the amino acid AA28. Interestingly, they were not able to bind and clear plaques, but they were able to improve behavioral changes in a transgenic mice model. Therefore, the question is, how may NAbs-A $\beta$ work if they can only recognize the mid-/C-endterminal part of $\mathrm{A} \beta$ ? According to recent solid-nuclear magnetic resonance spectroscopy studies of $\mathrm{A} \beta$ oligomerization, the $\mathrm{A} \beta$ residues $12-24$ and $30-40$ adopt $\beta$-strand conformations and form parallel [or antiparallel, according to a proposed model (Petkova et al., 2005)] $\beta$-sheets through intermolecular hydrogen bonding (Petkova et al., 2002). This process is followed by oligomerization of the $\mathrm{A} \beta$ peptides, as shown in Figure 6. After fibrillation, the C-terminal part of the $\mathrm{A} \beta$ peptide is masked. However, if an antibody is intended to block oligomerization, the C-terminal part of the $\mathrm{A} \beta$ peptide must be recognized for the antibody to bind to it. If an antibody recognizes the $\mathrm{N}$-terminal part of the $\mathrm{A} \beta$ peptide, oligomerization and fibrillation of the peptide may still continue. Therefore, to block these processes that result in plaque formation, an antibody appears to be useful that interferes with the $\mathrm{C}$-terminal part of the $\mathrm{A} \beta$ peptide.

In the active immunization studies, fibrillated $\mathrm{A} \beta$ peptide was used as antigen. It is likely that $\mathrm{N}$-terminal epitopes of the $\mathrm{A} \beta$ peptide were predominantly exposed and were available as binding sites. Accordingly, active immunization generated primarily antibodies that recognized the N-terminal epitope (AA4-10) of the $A \beta$ sequence (McLaurin et al., 2002). Furthermore, $\mathrm{A} \beta$ peptide is deposited in a fibrillar form in the plaques, and the $\mathrm{N}$-terminal part of the $\mathrm{A} \beta$ peptide is predominantly available at the "outside" of the plaque as an "epitope" for N-terminal active antibodies.

In contrast, NAbs- $A \beta$ - as mainly directed to the mid-/Cterminal epitope of $\mathrm{A} \beta$-were in fact not capable of binding to

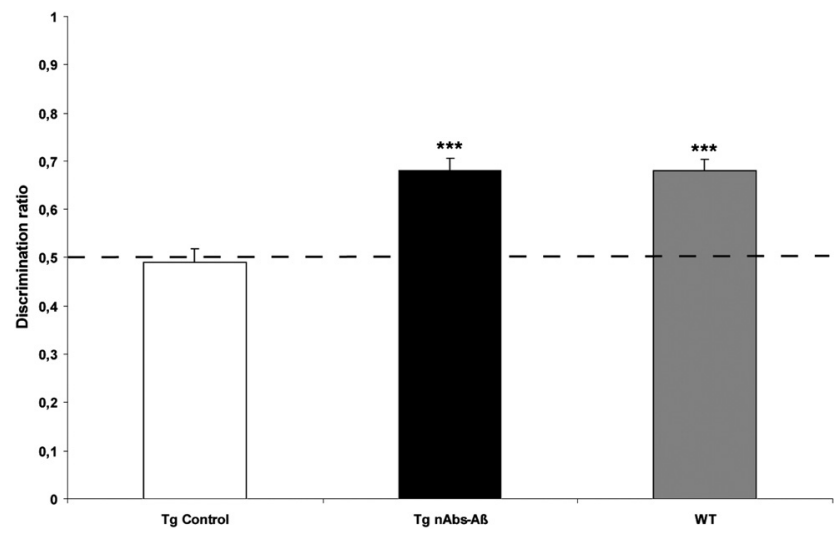

Figure 5. Neuropsychological testing in Tg2576 mice. Mean discrimination ratios for 14- to 16-month-old Tg2576 mice treated with either NAbs-A $\beta$ or PBS. NAbs-A $\beta$ immunized Tg2576 mice but not PBS-treated Tg2576 mice showed a preference for exploring objects moved to a new location, indicated by a discrimination ratio above 0.5 (NAbs-A $\beta$ group, $n=21$; PBS group, $n=20$; wild-type group, $n=20$; ${ }^{* * *} p<0.001$ ). Error bars show SEM. WT, Wild type.

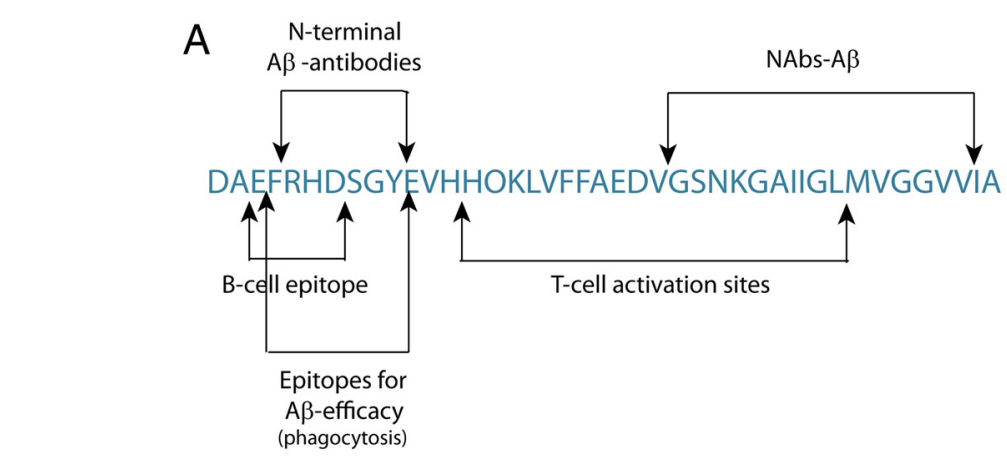

B
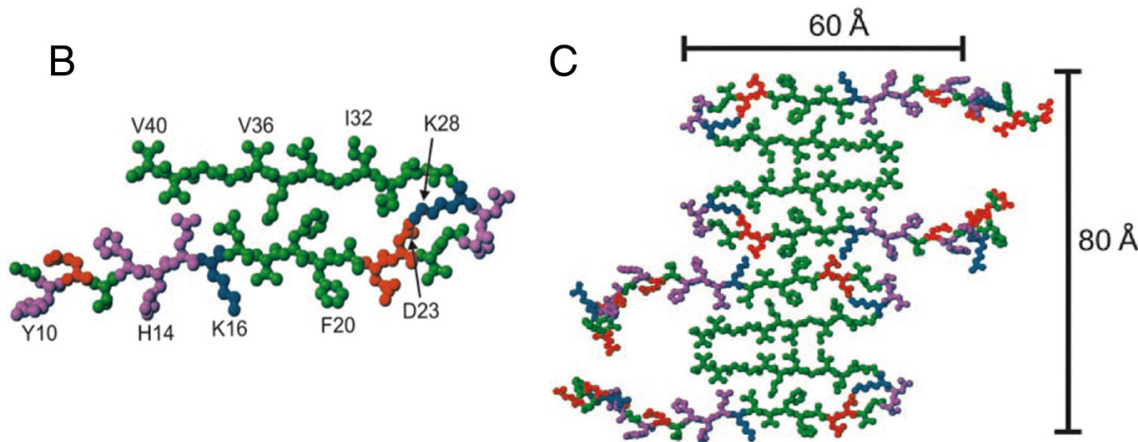

Figure 6. $\quad \boldsymbol{A}$, Currently known epitopes of the $A \beta$ sequence. The NAbs-A $\beta$ recognized a distinct C-terminal epitope compared with antibodies generated against the $\mathrm{N}$ terminus by active immunization in transgenic mice and promoted clearance of amyloid plaques (McLaurin et al., 2002). The T-cell activation sites and the B-cell epitope have been identified at AA14 -34 and AA4-10, respectively (Monsonego et al., 2001). $\boldsymbol{B}$, Assembly of $A \beta$ as proposed by Petkova et al. (2002, 2005). Central $A \beta_{1--40}$ molecules from the energy-minimized, five-chain system, viewed down the long axis of the fibril. Residues are color coded according to their side chains as hydrophobic (green), polar (magenta), positive (blue), or negative (red). C, Possible mode of lateral association for generating fibrils with greater mass-per-length and greater cross-sectional dimensions. Assembly of oligomers started at midterminal and C-terminal parts of the $A \beta$ peptide. Therefore, active immunization with $A \beta$ led to the generation of $\mathrm{N}$-terminal antibodies because only the $\mathrm{N}$-terminal part was available for T-cell interaction. Accordingly, only $\mathrm{N}$-terminal antibodies were effective in removing plaques because only $\mathrm{N}$-terminal parts were easily accessible to antibodies. In contrast, NAbs-A $\beta$ recognized the dimeric form of $A \beta$ and interfered with further assembly of monomers to oligomers. $\boldsymbol{B}$ and $\boldsymbol{C}$ are reproduced with permission from Proceedings of the National Academy of Sciences of the United States of America. the $\mathrm{N}$ terminus of $\mathrm{A} \beta$. This finding could also explain why our NAbs-A $\beta$ did not clear plaques.

Furthermore, we found that our NAbs-A $\beta$ preferentially bound to dimers and trimers and interfered with oligomerization (Britschgi et al., 2009). This may be the mechanisms why treat- 
ment with NAbs-A $\beta$ in young animals led to a reduction in plaque number and size, suggesting that they acted by preventing plaque formation.

Interestingly, $\mathrm{NAbs}-\mathrm{A} \beta$ failed to interact with other aggregating/ $\beta$-sheet promoting proteins, such as $\alpha$-synuclein and prion proteins (data not shown) (Du et al., 2003). Because naturally occurring antibodies do not bind to distinct protein sequences but rather recognize specific patterns of conservative molecules, we hypothesized that NAbs-A $\beta$ may recognize a common conformational epitope among those proteins; our current data, however, suggest that NAbs-A $\beta$ display a rather narrow epitopal recognition pattern.

Recently, Shankar et al. (2008) pinpointed small assemblies of $\mathrm{A} \beta$ as "disease causation of AD" (Shankar et al., 2008). This interaction with small oligomers is pivotal if NAbs-A $\beta$ play a role in the metabolism of $\mathrm{A} \beta$ peptides. However, targeting dissolved plaques is not the primary goal because these plaques are inert reservoirs ("garbage dump") and they help to trap toxic oligomers in the brain. Recent evidence from preclinical experimental studies as well as data from clinical trials support this notion (Holmes et al., 2008).

Although our data showed an efflux of central $A \beta$ into the periphery that favored the efflux hypothesis of $A \beta$ clearance (peripheral sink) (DeMattos et al., 2002), it was noticeable that a small amount of NAbs-A $\beta$ was capable of crossing the bloodbrain barrier and penetrating into the brain, as was shown using radiolabeled NAbs-A $\beta$ (Bacher et al., 2009). In previous studies, this small amount of autoantibodies available in the brain was suggested to be sufficient to induce uptake by opsonization in the brain (Schenk et al., 1999; Bard et al., 2000; Hock et al., 2002). Therefore, we cannot rule out that additional mechanisms, including a central degradation of $\mathrm{A} \beta$ oligomers in the presence of NAbs $-\mathrm{A} \beta$ by microglial cells, may occur in the brain.

In summary, we suggest that NAbs- $\mathrm{A} \beta$, as part of the autoantibody pool, have a physiological role and convey a protective effect by inhibiting oligomerization of $\mathrm{A} \beta$ peptides and consequently degrading $A \beta$. We further postulate that this protective effect is primarily mediated through interactions with the mid-/ $\mathrm{C}$-terminal parts of the $\mathrm{A} \beta$ peptide and may involve oligomerized products of $A \beta$. Furthermore, the increase of NAbs-A $\beta$ in the serum probably disrupts the equilibrium between central and peripheral $\mathrm{A} \beta$ pools, leading to a shift from the CNS to the periphery.

Finally, supportive evidence for the pivotal role that NAbs-A $\beta$ may play in the protection from $\mathrm{AD}$ comes from clinical studies using IVIg preparations that contain NAbs-A $\beta$. IVIg has shown a potentially positive effect on behavioral symptoms in $\mathrm{AD}$ patients (Dodel et al., 2004; Relkin et al., 2009). We are fully aware that these pilot studies only included a small number of patients. Nevertheless, these preliminary clinical results, along with our experimental results reported here, warrant a large clinical trial to investigate the effects of IVIg and human NAbs-A $\beta$ in patients with $\mathrm{AD}$. A respective phase-III trial is currently underway in the United States of America and results will be most likely available by 2013 .

\section{References}

Bacher M, Dodel R, Aljabari B, Keyvani K, Marambaud P, Kayed R, Glabe C, Goertz N, Hoppmann A, Sachser N, Klotsche J, Schnell S, Lewejohann L, Al-Abed Y (2008) CNI-1493 inhibits Abeta production, plaque formation, and cognitive deterioration in an animal model of Alzheimer's disease. J Exp Med 205:1593-1599.

Bacher M, Depboylu C, Du Y, Noelker C, Oertel WH, Behr T, Henriksen G, Behe M, Dodel R (2009) Peripheral and central biodistribution of
(111)In-labeled anti-beta-amyloid autoantibodies in a transgenic mouse model of Alzheimer's disease. Neurosci Lett 449:240-245.

Bard F, Cannon C, Barbour R, Burke RL, Games D, Grajeda H, Guido T, Hu K, Huang J, Johnson-Wood K, Khan K, Kholodenko D, Lee M, Lieberburg I, Motter R, Nguyen M, Soriano F, Vasquez N, Weiss K, Welch B, Seubert P, Schenk D, Yednock T (2000) Peripherally administered antibodies against amyloid beta-peptide enter the central nervous system and reduce pathology in a mouse model of Alzheimer disease. Nat Med 6:916-919.

Britschgi M, Olin CE, Johns HT, Takeda-Uchimura Y, LeMieux MC, Rufibach K, Rajadas J, Zhang H, Tomooka B, Robinson WH, Clark CM, Fagan AM, Galasko DR, Holtzman DM, Jutel M, Kaye JA, Lemere CA, Leszek J, Li G, Peskind ER, Quinn JF, Yesavage JA, Ghiso JA, Wyss-Coray T (2009) Neuroprotective natural antibodies to assemblies of amyloidogenic peptides decrease with normal aging and advancing Alzheimer's disease. Proc Natl Acad Sci U S A 106:12145-12150.

Chishti MA, Yang DS, Janus C, Phinney AL, Horne P, Pearson J, Strome R, Zuker N, Loukides J, French J, Turner S, Lozza G, Grilli M, Kunicki S, Morissette C, Paquette J, Gervais F, Bergeron C, Fraser PE, Carlson GA, George-Hyslop PS, Westaway D (2001) Early-onset amyloid deposition and cognitive deficits in transgenic mice expressing a double mutant form of amyloid precursor protein 695. J Biol Chem 276:21562-21570.

Cleary JP, Walsh DM, Hofmeister JJ, Shankar GM, Kuskowski MA, Selkoe DJ, Ashe KH (2005) Natural oligomers of the amyloid-beta protein specifically disrupt cognitive function. Nat Neurosci 8:79-84.

DeMattos RB, Bales KR, Cummins DJ, Dodart JC, Paul SM, Holtzman DM (2001) Peripheral anti-A beta antibody alters CNS and plasma A beta clearance and decreases brain A beta burden in a mouse model of Alzheimer's disease. Proc Natl Acad Sci U S A 98:8850-8855.

DeMattos RB, Bales KR, Cummins DJ, Paul SM, Holtzman DM (2002) Brain to plasma amyloid-beta efflux: a measure of brain amyloid burden in a mouse model of Alzheimer's disease. Science 295:2264-2267.

Dodart JC, Bales KR, Gannon KS, Greene SJ, DeMattos RB, Mathis C, DeLong CA, Wu S, Wu X, Holtzman DM, Paul SM (2002) Immunization reverses memory deficits without reducing brain Abeta burden in Alzheimer's disease model. Nat Neurosci 5:452-457.

Dodel R, Hampel H, Depboylu C, Lin S, Gao F, Schock S, Jäckel S, Wei X, Buerger K, Höft C, Hemmer B, Möller HJ, Farlow M, Oertel WH, Sommer N, Du Y (2002) Human antibodies against amyloid beta peptide: a potential treatment for Alzheimer's disease. Ann Neurol 52:253-256.

Dodel R, Neff F, Noelker C, Pul R, Du Y, Bacher M, Oertel W (2010) Intravenous immunoglobulins as a treatment for Alzheimer's disease: rationale and current evidence. Drugs 70:513-528.

Dodel RC, Du Y, Depboylu C, Hampel H, Frölich L, Haag A, Hemmeter U, Paulsen S, Teipel SJ, Brettschneider S, Spottke A, Nölker C, Möller HJ, Wei X, Farlow M, Sommer N, Oertel WH (2004) Intravenous immunoglobulins containing antibodies against beta-amyloid for the treatment of Alzheimer's disease. J Neurol Neurosurg Psychiatry 75:1472-1474.

Du Y, Dodel R, Hampel H, Buerger K, Lin S, Eastwood B, Bales K, Gao F, Moeller HJ, Oertel W, Farlow M, Paul S (2001) Reduced levels of amyloid beta-peptide antibody in Alzheimer disease. Neurology 57:801-805.

Du Y, Wei X, Dodel R, Sommer N, Hampel H, Gao F, Ma Z, Zhao L, Oertel WH, Farlow M (2003) Human anti-beta-amyloid antibodies block beta-amyloid fibril formation and prevent beta-amyloid-induced neurotoxicity. Brain 126:1935-1939.

Glabe CG (2008) Structural classification of toxic amyloid oligomers. J Biol Chem 283:29639-29643.

Hale G, Good M (2005) Impaired visuospatial recognition memory but normal object novelty detection and relative familiarity judgments in adult mice expressing the APPswe Alzheimer's disease mutation. Behav Neurosci 119:884-891.

Hock C, Konietzko U, Papassotiropoulos A, Wollmer A, Streffer J, von Rotz RC, Davey G, Moritz E, Nitsch RM (2002) Generation of antibodies specific for beta-amyloid by vaccination of patients with Alzheimer disease. Nat Med 8:1270-1275.

Holmes C, Boche D, Wilkinson D, Yadegarfar G, Hopkins V, Bayer A, Jones RW, Bullock R, Love S, Neal JW, Zotova E, Nicoll JA (2008) Long-term effects of Abeta42 immunisation in Alzheimer's disease: follow-up of a randomised, placebo-controlled phase I trial. Lancet 372:216-223.

Hsiao K, Chapman P, Nilsen S, Eckman C, Harigaya Y, Younkin S, Yang F, Cole G (1996) Correlative memory deficits, Abeta elevation, and amyloid plaques in transgenic mice. Science 274:99-102. 
Imboden M, Murphy KR, Rakhmilevich AL, Neal ZC, Xiang R, Reisfeld RA, Gillies SD, Sondel PM (2001) The level of MHC class I expression on murine adenocarcinoma can change the antitumor effector mechanism of immunocytokine therapy. Cancer Res 61:1500-1507.

Jia CY, Nie J, Wu C, Li C, Li SS (2005) Novel Src homology 3 domainbinding motifs identified from proteomic screen of a Pro-rich region. Mol Cell Proteomics 4:1155-1166.

Kaether C, Schmitt S, Willem M, Haass C (2006) Amyloid precursor protein and Notch intracellular domains are generated after transport of their precursors to the cell surface. Traffic 7:408-415.

Kayed R, Head E, Thompson JL, McIntire TM, Milton SC, Cotman CW, Glabe CG (2003) Common structure of soluble amyloid oligomers implies common mechanism of pathogenesis. Science 300:486-489.

Khandogin J, Brooks CL 3rd (2007) Linking folding with aggregation in Alzheimer's beta-amyloid peptides. Proc Natl Acad Sci U S A 104: $16880-16885$

Klyubin I, Walsh DM, Lemere CA, Cullen WK, Shankar GM, Betts V, Spooner ET, Jiang L, Anwyl R, Selkoe DJ, Rowan MJ (2005) Amyloid beta protein immunotherapy neutralizes Abeta oligomers that disrupt synaptic plasticity in vivo. Nat Med 11:556-561.

Lesné S, Koh MT, Kotilinek L, Kayed R, Glabe CG, Yang A, Gallagher M, Ashe $\mathrm{KH}$ (2006) A specific amyloid-beta protein assembly in the brain impairs memory. Nature 440:352-357.

Lovasic L, Bauschke H, Janus C (2005) Working memory impairment in a transgenic amyloid precursor protein TgCRND8 mouse model of Alzheimer's disease. Genes Brain Behav 4:197-208.

Mangialasche F, Solomon A, Winblad B, Mecocci P, Kivipelto M (2010) Alzheimer's disease: clinical trials and drug development. Lancet Neurol 9:702-716.

McLaurin J, Cecal R, Kierstead ME, Tian X, Phinney AL, Manea M, French JE, Lambermon MH, Darabie AA, Brown ME, Janus C, Chishti MA, Horne P, Westaway D, Fraser PE, Mount HT, Przybylski M, St George-Hyslop P (2002) Therapeutically effective antibodies against amyloid-beta peptide target amyloid-beta residues 4-10 and inhibit cytotoxicity and fibrillogenesis. Nat Med 8:1263-1269.

Monsonego A, Maron R, Zota V, Selkoe DJ, Weiner HL (2001) Immune hyporesponsiveness to amyloid beta-peptide in amyloid precursor protein transgenic mice: implications for the pathogenesis and treatment of Alzheimer's disease. Proc Natl Acad Sci U S A 98:10273-10278.

Morgan D, Diamond DM, Gottschall PE, Ugen KE, Dickey C, Hardy J, Duff K, Jantzen P, DiCarlo G, Wilcock D, Connor K, Hatcher J, Hope C, Gordon M, Arendash GW (2000) A beta peptide vaccination prevents memory loss in an animal model of Alzheimer's disease. Nature 408: 982-985.

Petkova AT, Ishii Y, Balbach JJ, Antzutkin ON, Leapman RD, Delaglio F, Tycko R (2002) A structural model for Alzheimer's beta -amyloid fibrils based on experimental constraints from solid state NMR. Proc Natl Acad Sci U S A 99:16742-16747.

Petkova AT, Leapman RD, Guo Z, Yau WM, Mattson MP, Tycko R (2005)
Self-propagating, molecular-level polymorphism in Alzheimer's betaamyloid fibrils. Science 307:262-265.

Rajendran L, Honsho M, Zahn TR, Keller P, Geiger KD, Verkade P, Simons K (2006) Alzheimer's disease beta-amyloid peptides are released in association with exosomes. Proc Natl Acad Sci U S A 103:11172-11177.

Relkin NR, Szabo P, Adamiak B, Burgut T, Monthe C, Lent RW, Younkin S, Younkin L, Schiff R, Weksler ME (2009) 18-Month study of intravenous immunoglobulin for treatment of mild Alzheimer disease. Neurobiol Aging 30:1728-1736.

Röskam S, Neff F, Schwarting R, Bacher M, Dodel R (2010) APP transgenic mice: the effect of active and passive immunotherapy in cognitive tasks. Neurosci Biobehav Rev 34:487-499.

Schenk D, Barbour R, Dunn W, Gordon G, Grajeda H, Guido T, Hu K, Huang J, Johnson-Wood K, Khan K, Kholodenko D, Lee M, Liao Z, Lieberburg I, Motter R, Mutter L, Soriano F, Shopp G, Vasquez N, Vandevert C, Walker S, Wogulis M, Yednock T, Games D, Seubert P (1999) Immunization with amyloid-beta attenuates Alzheimer-disease-like pathology in the PDAPP mouse. Nature 400:173-177.

Selkoe DJ (2004) Cell biology of protein misfolding: the examples of Alzheimer's and Parkinson's diseases. Nat Cell Biol 6:1054-1061.

Shankar GM, Li S, Mehta TH, Garcia-Munoz A, Shepardson NE, Smith I, Brett FM, Farrell MA, Rowan MJ, Lemere CA, Regan CM, Walsh DM, Sabatini BL, Selkoe DJ (2008) Amyloid-beta protein dimers isolated directly from Alzheimer's brains impair synaptic plasticity and memory. Nat Med 14:837-842.

Shoenfeld Y, Gershwin ME, Meroni PL (2007) Autoantibodies. Burlington: Elsevier Science and Technology.

Sturchler-Pierrat C, Abramowski D, Duke M, Wiederhold KH, Mistl C, Rothacher S, Ledermann B, Burki K, Frey P, Paganetti PA, Waridel C, Calhoun ME, Jucker M, Probst A, Staufenbiel M, Sommer B (1997) Two amyloid precursor protein transgenic mouse models with Alzheimer disease-like pathology. Proc Natl Acad Sci U S A 94:13287-13292.

Taguchi H, Planque S, Nishiyama Y, Symersky J, Boivin S, Szabo P, Friedland RP, Ramsland PA, Edmundson AB, Weksler ME, Paul S (2008) Autoantibody-catalyzed hydrolysis of amyloid beta peptide. J Biol Chem 283:4714-4722.

Tomic JL, Pensalfini A, Head E, Glabe CG (2009) Soluble fibrillar oligomer levels are elevated in Alzheimer's disease brain and correlate with cognitive dysfunction. Neurobiol Dis 35:352-358.

Townsend M, Shankar GM, Mehta T, Walsh DM, Selkoe DJ (2006) Effects of secreted oligomers of amyloid beta-protein on hippocampal synaptic plasticity: a potent role for trimers. J Physiol 572:477-492.

Walsh DM, Townsend M, Podlisny MB, Shankar GM, Fadeeva JV, El Agnaf O, Hartley DM, Selkoe DJ (2005) Certain inhibitors of synthetic amyloid $\beta$-peptide $(\mathrm{A} \beta)$ fibrillogenesis block oligomerization of natural $\mathrm{A} \beta$ and thereby rescue long-term potentiation. J Neurosci 25:2455-2462.

Weksler ME, Relkin N, Turkenich R, LaRusse S, Zhou L, Szabo P (2002) Patients with Alzheimer disease have lower levels of serum anti-amyloid peptide antibodies than healthy elderly individuals. Exp Gerontol 37:943948. 